\title{
Taal, vertaling en beleid in de XXle eeuw
}

Reine Meylaerts

\section{INLEIDING}

"Alleen Nederlands op markt in Merchtem - De gemeenteraad van Merchtem heeft gisteravond beslist dat handelaars op de woensdagmarkt alleen nog Nederlandstalige affiches en opschriften mogen uithangen. Een aantal van hen gebruiken momenteel ook Franse of Arabische teksten, en dat mag voortaan niet meer", zo was er te lezen in De Standaard van 25 oktober 2005. Met een zekere regelmaat duiken in de Nederlandstalige en Franstalige pers in België gelijkaardige berichten op over taalstrubbelingen. Zo vernemen we in dezelfde krant dat 'een Vlaamse pastoor in de faciliteitengemeente Sint-Genesius-Rode weigert een Franstalige inwoner te begraven omdat diens familie een tweetalige uitvaartdienst vraagt. De familie is verontwaardigd' (De Standaard 14 oktober 2008). Andere items betreffen het taalgebruik aan de loketten van openbare diensten of in ziekenhuizen, speelpleinen waar kinderen alleen Nederlands horen te spreken, bouwgronden of sociale woningen voorbehouden aan Nederlandstaligen. Het voorbije jaar kwam daar nog het welles-nietesspelletje over de benoeming van de burgemeesters uit drie faciliteitengemeenten rond Brussel bovenop. Om nog maar te zwijgen van Brussel-Halle-Vilvoorde ... Kortom, iedere Belg weet dat het niet moeilijk zou zijn om een ellenlange lijst op te stellen van taalconflicten - het ene al onschuldiger dan het andere. België op zijn smalst? 
Als we even naar het buitenland kijken, blijkt al gauw dat deze op het eerste gezicht typisch Belgische taaltwisten helemaal niet het monopolie zijn van de slechtste leerling van de Europese klas. Zo werd de Canadese provincie Quebec in het verleden door de Verenigde Naties op de vingers getikt voor haar pogingen om niet-Franstalige winkelborden te verbieden. En niet alleen in officieel meertalige landen zoals België, Canada, Spanje of Zuid-Afrika, maar ook in eentalige staten worden er geschillen beslecht over het gebruik van talen en het recht op vertaling in de publieke sfeer of in openbare instellingen. In de Verenigde Staten hebben dertig deelstaten, waaronder Californië, Florida en Georgia, het Engels als officiële taal erkend (weliswaar met verschillen tussen de staten onderling), maar ook hier duiken regelmatig taal- en vertaaltwisten op. In Atlanta (Georgia) bijvoorbeeld, hebben Spaanstalige handelaars een boete moeten betalen omdat ze een wet hadden overtreden die bepaalt dat reclameopschriften voor minstens $75 \%$ in het Engels moeten zijn. Hun 'supermercado' moest worden vertaald in 'supermarket' (Schildkraut 2005: 1).

$\mathrm{Al}$ deze voorbeelden illustreren dat disputen en reglementeringen rond taal en vertaling integraal deel uitmaken van op het eerste gezicht erg uiteenlopende hedendaagse maatschappijen. Of we het nu hebben over metropolen zoals Brussel, New York of Londen (Blackledge 2005), over officieel meertalige landen zoals België, Zuid-Afrika (Beukes 2006 en 2007), Canada, Spanje of over officieel eentalige staten met belangrijke migrantenminderheden zoals sommige deelstaten van de Verenigde Staten (Schildkraut 2005), ze hebben één ding gemeen: hun overheden worden geconfronteerd met meertalige bevolkingsgroepen waarmee en waartussen de communicatie niet altijd even vlot verloopt. Maar wat is hier eigenlijk precies aan de hand? Waarom wordt er over taal en vertaling gebakkeleid? Gaat het enkel over een paar heethoofden, stijfkoppen of onwetenden? Of staat er meer op het spel?

\section{TAAL, VERTALING EN INSTITUTIONALISERING}

De diepere oorzaak van de twisten heeft te maken met het toekennen van rechten rond taalgebruik en vertaling aan burgers in de moderne natiestaat. Een natiestaat is een staatsvorm die ontwikkeld is om de structuren van het ancien régime te vervangen. Met de Franse revolutie werd het principe van de goddelijke macht van de vorst vervangen door de soevereiniteit van het volk. De steun en consensus van het volk werd van primordiaal belang voor de legitimatie van het gezag in de zich daarop ontwikkelende 
moderne natiestaten. Legitimering van het gezag door het volk veronderstelt onder andere communicatie tussen het volk en de machthebbers: iedere burger heeft het recht om te communiceren met de overheid en omgekeerd moet de overheid haar burgers kunnen bereiken. Daarom zijn burgerrechten verbonden met taalrechten en met recht op vertaling. Deze rechten krijgen vorm in een taal- en vertaalbeleid dat naast rechten ook plichten en voorwaarden rond taalgebruik en vertaling inhoudt.

Laten we het eerst hebben over het zogenaamde taalbeleid. Overheden verbinden bepaalde rechten (bijvoorbeeld stemrecht) en het verstrekken van bepaalde diensten (onderwijs, administratie, justitie) aan het gebruik van één of meerdere officiële, vaak zogenaamde nationale talen waarvan ze de principes wettelijk vastleggen, vaak al in de grondwet. Zo vermeldt artikel 2 van de Franse grondwet van 4 oktober 1958: 'La langue de la République est le français' (http://www.assemblee-nationale.fr/connaissance/ constitution_1209.pdf). Dit taalbeleid, dit reglementeren van taal in instituties en de daaraan verbonden rechten en plichten, is niet van toepassing op het gebruik van talen in de privésfeer dat in principe volledig vrij is. In familiale kring, tijdens een avondje uit met vrienden, tegen een toevallige voorbijganger op straat, in chatrooms op het internet enzovoort gebruikt een individu vaak een veelheid aan talen, typisch voor het leven in de huidige meertalige geglobaliseerde wereld. Maar als diezelfde persoon van bepaalde rechten wil gebruik maken, als hij/zij onderwijs wil volgen in zijn/haar buurt, als hij/zij wil geholpen worden aan het loket van een overheidsdienst, als hij/zij wil gaan stemmen, dan ziet de situatie er ineens heel anders uit. Aan het uitoefenen van deze rechten of het bekomen van deze diensten zijn bepaalde taalvoorwaarden verbonden die de overheid meestal strikt vastlegt. Vaak komt het erop neer dat overheden een reductie doorvoeren met betrekking tot het aantal talen dat gebruikt kan worden - we komen hier nog uitgebreid op terug. Met andere woorden, de taaldiversiteit van de bevolking wordt zelden of nooit volledig weerspiegeld in het taalbeleid van een overheid. Sommige talen blijken privileges te hebben waarover anderen niet beschikken. Deze ongelijkheid is geen gevolg van eventuele kwaliteitsverschillen of waardeverschillen tussen de talen in kwestie. Ze is een gevolg van de ongelijke institutionalisering van de verschillende talen in een samenleving waardoor sommige talen een voorkeursbehandeling genieten in vergelijking met andere. Allerhande wettelijke regelingen bepalen welke de legitieme taal (of talen) is (of zijn) op een bepaald ogenblik, in een bepaalde institutionele context.

Taal en taalbeleid spelen dus een belangrijke rol in samenlevingen die participerend burgerschap nastreven. Wat is (of zijn) de taal (of talen) van de 
administratie, van de politieke instellingen, van het onderwijs, van justitie, van het leger ... waarmee een overheid met haar burgers communiceert? De verschillende mogelijke opties voor implementatie zijn allesbehalve onschuldig. Ze verlenen of ontzeggen fundamentele rechten, en ze dragen bij tot de creatie of transformatie van identiteit en van machtsrelaties tussen verschillende talen en hun sprekers. Ze versterken of verzwakken de grenzen tussen groepen in een samenleving (Blackledge 2005: 174). Ze zijn dus verbonden met taalideologieën. Het ideaal van participerend burgerschap heeft met andere woorden de taalrelaties gepolitiseerd. Terwijl in premoderne samenlevingen bevolkingsgroepen zich niet in de eerste plaats identificeren met een bepaalde taal maar met een lokale gemeenschap (bijvoorbeeld het dorp) of met een bepaalde klasse (zoals de adel of de gilden) of met een confessionele groep (de katholieken) (Huyse 1983:9), identificeren hedendaagse burgers zich ook met een bepaalde geïnstitutionaliseerde taal die hun bepaalde rechten geeft, waaronder het fundamentele recht om met de autoriteiten te communiceren. Het is dus niet verwonderlijk dat hierover allerhande taaltwisten ontstaan. Meer nog, naarmate de mobiliteit toeneemt, naarmate hedendaagse maatschappijen meer en meer geconfronteerd worden met belangrijke migratiestromen dreigt de kloof tussen het taalbeleid enerzijds en de taaldiversiteit van de bevolking anderzijds alleen maar te groeien.

Vandaar het toenemend belang van een zogenaamd vertaalbeleid. Indien we ervan uitgaan dat de rechten van burgers in belangrijke mate verbonden zijn met hun taalrechten, dan is ook de implementatie van hun recht op vertaling een integraal en fundamenteel deel van het debat rond de rechten van minderheden en, meer in het algemeen van politieke en ideologische debatten in de huidige meertalige samenlevingen. Om de mechanismen van inclusie en exclusie in de moderne maatschappijen te verstaan, is er inzicht nodig in de geschiedenis en dynamiek van hun taal- én vertaalbeleid, want taal- en vertaalbeleid zijn onlosmakelijk met elkaar verbonden. Geen taalbeleid zonder vertaalbeleid. Niet alleen de vraag welke taal (of talen) in nationale, regionale of lokale instellingen geïnstitutionaliseerd is (of zijn), maar ook, en noodzakelijkerwijze, de vraag wat wel of niet vertaald mag worden op een bepaald ogenblik in een bepaalde institutionele context, is deel van de strijd voor inclusie en exclusie. Het ideaal van participerend burgerschap creëert dus nieuwe noden en uitdagingen voor taal- én vertaalbeleid in de eenentwintigste eeuw. Inderdaad, indien een van de grootste uitdagingen voor participerend burgerschap taal is (Stroud en Heugh 2004: 213), dan geldt hetzelfde voor vertaling. De analyse van het vertaalbeleid, vanuit synchroon of diachroon oogpunt, vormt daarom een essentieel onderdeel van de studie van taalbeleid en haar relatie met 
participerend burgerschap, nationale identiteit, minderheden, migratie, globalisering, taalrechten, taalideologieën enzovoort.

Toch moeten we hier een opvallende leemte in het onderzoek vaststellen. In de vele studies rond taalrechten, taalbeleid en taalideologieën wordt de sleutelrol van vertaling zelden of nooit onderzocht (voor enkele voorbeelden, zie Blommaert 1999, Patten en Kymlicka 2003, Freeland en Patrick 2004, Vermeulen en Slijper 2003, Van Parijs 2007). Kaplan en Baldauf (1997) en Beukes (2006 en 2007) behoren tot de uitzonderingen die naast taalbeleid ook vertaalbeleid in hun onderzoek betrekken. In haar studies toont Beukes bijvoorbeeld hoe het gebrek aan vertaalbeleid in Zuid-Afrika, een land met maar liefst elf officiële talen, bijgedragen heeft tot het verdwijnen van bepaalde inheemse talen in bepaalde socioculturele sectoren. Binnen de discipline van de vertaalwetenschap wordt ook slechts uitzonderlijk ingegaan op het verband tussen taal- en vertaalbeleid (zie Cronin 1995, García González 2004, Branchadell 2004, García de Toro 2004, Meylaerts 2009).

Welk taal- en vertaalbeleid voor welke linguïstische minderheden? Wat is de rol en het statuut van institutionele vertaling in een bepaalde maatschappij? Hoe evolueert ze? Wat is het verband tussen verschillende types van vertaalbeleid en het bevorderen van integratie van minderheden of het behoud van een eigen taal en identiteit? Hoe dragen reguleringen en restricties met betrekking tot het recht op institutionele vertaling bij tot het creëren of tenietdoen van machtsrelaties tussen verschillende talen en hun sprekers? Welke rol hebben ze in de implementering van participerend burgerschap of van taalrechten? Dit zijn slechts enkele voorbeelden van fundamentele vragen. Omwille van een gebrek aan grootschalig vergelijkend onderzoek naar taal- en vertaalbeleid in vroegere en hedendaagse maatschappijen ontbreken voor het ogenblik duidelijke antwoorden. Vele ad hoc maatregelen illustreren de aarzelingen of zelfs de dilemma's waarmee hedendaagse overheden geconfronteerd worden in hun taal- en vertaalbeleid. De aangehaalde voorbeelden van taal- en vertaaltwisten moeten in het licht hiervan begrepen worden. Taal- en vertaalbeleid moeten inderdaad functioneren in een complex web van conflicterende factoren. De impact van een bepaalde maatregel kan, naargelang de context, zowel emanciperend als onderdrukkend overkomen. Een voorbeeld. Wat lijkt er rechtvaardiger dan onderwijs in eigen taal? Tijdens het apartheidsregime in Zuid-Afrika werd de moedertaal verplicht als onderwijstaal in het lager onderwijs in zwarte zogenaamde Bantoescholen, die beduidend minder financiële middelen kregen dan blanke scholen (Leman en Top 2006: 68). Het gevolg was dat moedertaalonderwijs geassocieerd werd met minderwaardig onderwijs en met verminderde slaagkansen. Aanleiding voor de 
bloedige rellen van 1976 in Soweto was de bijkomende maatregel dat voor de hogere graden niet meer het Engels maar het Afrikaans als onderwijstaal diende gebruikt te worden. Dat verminderde opnieuw de slaagkansen van de zwarte kinderen.

Betekent dit dat moedertaalonderwijs voor minderheden een discriminerende maatregel is? Zo eenvoudig is het uiteraard niet. Aangezien er zich niet zomaar pasklare oplossingen aanbieden, is het raadzaam een aantal mogelijke systemen van taal- en vertaalbeleid te analyseren en met elkaar te vergelijken. In wat volgt zal ik daartoe een tentatieve typologie van taalen vertaalbeleid en de mogelijke impact ervan op de rechten van minderheden voorstellen. Ze is deels gebaseerd op de geschiedenis van het taal- en vertaalbeleid in België vanaf 1830 tot nu, deels op voorbeelden uit andere contexten (Verenigde Staten, Canada, Verenigd Koninkrijk, Spanje). Om van hieruit concrete beleidsmaatregelen te implementeren moet deze typologie verder ontwikkeld en uitgetest worden in grootschaliger interdisciplinair onderzoek.

\section{INSTITUTIONELE EENTALIGHEID EN VERBOD OP VERTALING}

Laten we vertrekken van een veelvoorkomende alledaagse situatie, waar de eentaligheid van de (nationale, regionale, lokale) instellingen contrasteert met de taaldiversiteit van de bevolking.

There are now more than three hundred languages spoken in London alone (...). (...) while the linguistic landscape has certainly changed, the predominant ideology in relation to minority languages other than English remains little altered. That is, in political, media and other public discourse, a monolingual ideology still obtains, despite clear evidence that more than three hundred languages are in regular and robust use in towns and cities across the country. There is a clear mismatch between the multilingualism of the people and the monolingualism of the dominant ideology. (Blackledge 2005: 65)

In zo'n situatie is de institutionele hiërarchie tussen de verschillende talen zeer uitgesproken. De niet of weinig geïnstitutionaliseerde talen (we noemen ze vanaf nu gemakshalve minderheidstalen zonder dat deze term 
noodzakelijk verwijst naar het aantal sprekers) zijn min of meer uitgesloten uit belangrijke maatschappelijke domeinen zoals politiek, gerecht, administratie, onderwijs. Uiteraard kan de graad van institutionalisering tussen de minderheidstalen onderling verschillen en kunnen er evoluties doorheen de tijd optreden. Een bepaalde minderheidstaal kan bijvoorbeeld geïnstitutionaliseerd zijn op het niveau van de lokale, maar niet dat van de nationale administratie; een bepaalde minderheidsgroep kan recht hebben op lager onderwijs maar niet op secundair of hoger, universitair onderwijs in haar minderheidstaal; een bepaalde groep kan financiële steun krijgen om kranten in haar taal te publiceren, of om radio of televisie in haar taal aan te bieden enzovoort. Al deze vormen van institutionalisering hebben gevolgen voor de taalrechten van de betrokken minderheden. Talen zijn, zoals reeds aangehaald, verbonden met macht en prestige, en taalbeleid draagt bij tot fenomenen van insluiting en uitsluiting. Dit is nog steeds het geval in vele natiestaten, die omwille van hun ideaal van participerend burgerschap gebaseerd zijn op een monolinguale ideologie (Anderson 1991, Hymes 1996, Heller 1995 en 1999). In het negentiende-eeuwse België bijvoorbeeld was Frans de taal van de administratie, het gerecht, het onderwijs en het leger, terwijl Nederlands, alhoewel het de taal van de meerderheid van de Belgen was, de niet of minder geïnstitutionaliseerde minderheidstaal was. Hetzelfde geldt voor de linguïstische minderheden in de hedendaagse grootsteden zoals Londen, New York, Brussel, Madrid enzovoort, waar er een duidelijke wanverhouding bestaat tussen de meertaligheid van de bevolking en de eentaligheid van de instellingen (Blackledge 2005: 65). Om een universitair diploma te behalen, om te slagen in het politieke, economische leven en in de media, kortom, om op te klimmen op de sociale ladder, moeten linguïstische minderheden best de geïnstitutionaliseerde meerderheidstaal (of -talen) kennen of aanleren. En dat is precies de reden waarom ze tweetalig of meertalig worden. Meer nog, vaak ontstaat er binnen deze groepen een linguïstische transfer na een of meerdere generaties: linguïstische minderheden spreken niet meer hun moedertaal maar de meerderheidstaal, ook in privésituaties.

Maar een taalbeleid dat zich kenmerkt door institutionele eentaligheid gaat per definitie gepaard met een specifiek vertaalbeleid. Zoals gezegd, geen taalbeleid zonder vertaalbeleid. In zijn meest extreme vorm steunt dit vertaalbeleid op een combinatie van verbod op vertaling en verplichting tot vertaling.

1. De verplichting om te vertalen heeft betrekking op vertaling in de geïnstitutionaliseerde meerderheidstaal en vormt een noodzakelijke voorwaarde voor institutionele eentaligheid. Ze is van toepassing op bij- 
voorbeeld alle anderstalige (administratieve, politieke, wettelijke) boodschappen en documenten, of deze nu komen van de lokale minderheden of van externe instellingen of overheden. Anderstalige boodschappen en documenten zijn enkel en alleen rechtsgeldig indien ze beschikbaar en dus vertaald zijn in de taal die door de overheid geïnstitutionaliseerd is binnen haar territorium. Institutioneel monolinguïsme is inderdaad vaak verbonden met het principe van territorialiteit (zie ook Van Parijs 2007). Zo bijvoorbeeld moeten alle Europese richtlijnen vertaald worden in de verschillende geïnstitutionaliseerde talen van de deelstaten (Frankrijk, Duitsland enzovoort) of regio's (Vlaanderen) om geldig te zijn in die verschillende deelstaten. Dit betekent dat het Europese vertaalbeleid de invulling van participerend burgerschap via institutionele eentaligheid ondersteunt. Communicatie tussen de Europese burgers en de Europese overheid gebeurt in de nationale taal van de burger.

Verplichte institutionele vertaling in de meerderheidstaal, met andere woorden, helpt de dominantie van de meerderheidstaal te verzekeren en is een noodzakelijke voorwaarde voor het continueren van institutionele eentaligheid. Vermits deze vertaalmodaliteit bijdraagt tot het gebrek aan legitimiteit van de minderheidstalen en hun sprekers, zijn zij hier niet onverdeeld voorstander van. In het bijzonder wanneer deze minderheden ijveren voor de institutionele emancipatie van hun minderheidstaal, wanneer ze gelijke institutionele rechten proberen te verkrijgen voor hun eigen taal, kanten ze zich tegen dit type vertaalbeleid. Dat was precies de houding van sommige Nederlandstaligen in België die tijdens de negentiende eeuw en in het begin van de twintigste eeuw ijverden voor de institutionalisering van het Nederlands, onder andere in de administratie. De onvermijdelijke vertaling in het Frans als gevolg van de administratieve eentaligheid, moest het ontgelden.

Actuellement, dans beaucoup de services, lorsqu'il entre un dossier concernant une affaire introduite par un particulier ou une administration locale, en langue flamande, ce dossier nest pas étudié sur les pièces originales. Il passe d'abord au bureau des traductions et les pièces flamandes en sortent agrémentées d'une traduction, inscrite quelquefois - cétait la pratique aux chemins de fer - en texte interlinéaire à l'encre rouge. Le fonctionnaire responsable chargé d'étudier l'affaire et de proposer une solution au ministre forme son opinion sur la traduction. Il nest pas difficile d'apercevoir les inconvénients et les risques de ce système. 
Faut-il sétonner que les administrés un peu au courant de la pratique suivie désirent échapper au traducteur - traduttore traditore - et s'efforcent de traiter eux-mêmes l'affaire en français?

Quant aux explications verbales que l'administré flamand désirerait donner à l'administration supérieure, il vaut mieux, n'est-ce pas, n'en pas parler ? Il se heurtera certainement à un interprète.

Aussi, tant que persistera la situation actuelle, le nombre d'affaires traitées en flamand restera fort restreint, et il ne sera pas difficile aux administrations de prétendre, d'après les données statistiques, que les administrés montrent une préférence extraordinaire pour la langue française. (Van de Vyvere 1919: 20)

Verplichte vertaling in de meerderheidstaal kan dus bijdragen tot de continuering van een eentalige ideologie. Vertaling, ondanks het algemeen aanvaarde cliché, heeft niet altijd een emanciperende functie voor linguïstische minderheden.

2. Het verbod om te vertalen heeft betrekking op de omgekeerde richting, dat wil zeggen, op legale, juridische, administratieve vertaling uit de meerderheidstaal in de minderheidstaal of -talen binnen een nationale, regionale of stedelijke context van geïnstitutionaliseerde eentaligheid. Zo bepaalt de 'S.I. Hayakawa National Language Amendment Act of 2007', gestemd door de Amerikaanse Senaat in juni 2007 dat Engels de nationale taal is van de regering van de Verenigde Staten. Om de rol van de nationale taal te bewaren en te versterken, bepaalt ze verder dat:

- (a) In General - The Government of the United States shall preserve and enhance the role of English as the national language of the United States of America.

- (b) Exception - Unless specifically provided by statute, no person has a right, entitlement, or claim to have the Government of the United States or any of its officials or representatives act, communicate, perform or provide services, or provide materials in any language other than English. If an exception is made with respect to the use of a language other than English, the exception does not create a legal entitlement to additional services in that language or any language other than English.

- (c) Forms - If any form is issued by the Federal Government in a language other than English (or such form is completed in a language other than English), the English language version of the form is 
the sole authority for all legal purposes. (www.govtrack.us/congress/ amendment.xpd? session $=110$ \&amdt $=$ s1151)

Met andere woorden, anderstalige minderheden in de Verenigde Staten hebben geen affirmatief recht om van de federale regering een vertaling uit het Engels in een van de minderheidstalen te eisen. Het federaal niveau verbiedt met dit vertaalbeleid het recht op vertaling in de minderheidstalen. Een gelijkaardig vertaalbeleid werd in het negentiende-eeuwse België gevoerd. Omwille van het institutionele monopolie van het Frans was wettelijke, administratieve en gerechtelijke vertaling in het Nederlands geen afdwingbaar recht. Dit had gevolgen voor het leger, voor de administratie, voor de politieke instellingen, voor het gerecht enzovoort: oorspronkelijk functioneerden al deze instellingen de facto eentalig. De gevolgen van een vertaalverbod kunnen echter verregaand zijn. Zo kennen de meeste Vlamingen wel de boutade 'Et pour les Flamands la même chose', die teruggaat op het taal- en vertaalbeleid in het Belgische leger. In 1830 besliste het Voorlopig Bewind dat in het leger enkel het Frans zou gebruikt worden als commandotaal (Wils 1991: 54). In plaats van met een Nederlandse vertaling beëindigden de Franstalige officieren hun instructies tijdens de opleiding dan ook vaak met 'Et pour les Flamands la même chose. Tijdens de Eerste Wereldoorlog zou dit beleid van niet-vertaling volgens sommige Vlaamsgezinden zelfs levens gekost hebben. De infanterie was samengesteld uit ongeschoolde jongeren waarvan 70\% Fransonkundige Vlamingen, terwijl de officieren Franstalig waren. Volgens de tegenstanders van het toenmalige taal- en vertaalbeleid vonden vele soldaten de dood, omdat ze de Franstalige bevelen van hun oversten niet verstonden.

Op gerechtelijk vlak bestonden er gelijkaardige situaties. In de zaak CouckeGoethals bijvoorbeeld werden in 1860 twee Vlaamse werklieden 'voor het Assisenhof van Henegouwen ter dood veroordeeld en gehalsrecht zonder dat zij hun proces hadden verstaan' (Luykx 1985: 161). Achteraf bleek 'dat zij in geen geval de hoofdschuldigen waren in de moord' (Luykx 1985:161) waarvoor zij terechtstonden. Ook in de administratie heeft het verbod op vertaling sporen nagelaten. Toen Domien Sleeckx in 1844 in Brussel een Nederlandstalige geboorteakte voor zijn kind eiste, werd hij hiervoor veroordeeld (Luykx 1985: 161). Of nog, in 1872, deed een 'fransonkundige werkman' uit Sint-Jans-Molenbeek aangifte van de geboorte van zijn zoon in het Nederlands. 'Hij werd veroordeeld tot een geldboete van $50 F$, omdat hij weigerde de Franse verklaring, die hij niet verstond, te ondertekenen' (Luykx 1985:161).

Vertaling, met andere woorden, is geen afdwingbaar recht in een meertalige maatschappij die participerend burgerschap min of meer exclusief voorbe- 
houdt voor die burgers die de geïnstitutionaliseerde meerderheidstaal verstaan. Institutionele eentaligheid in combinatie met verbod op vertaling kan dus sociale structuren van ongelijkheid en uitsluiting van linguïstische minderheden in meertalige maatschappijen versterken.

\section{VERTALEN VOOR DE MINDERHEDEN}

Precies daarom is dit type taal- en vertaalbeleid - institutioneel monolinguïsme met verplichte vertaling in de meerderheidstaal en afwezigheid van of zelfs verbod op vertaling in de minderheidstalen - eerder uitzonderlijk in een democratische samenleving. Het staat haaks op het ideaal van participerend burgerschap en inclusie van de moderne natiestaat. Zeker in de huidige meertalige samenlevingen met hun niet-aflatende migratiestromen werkt dit taal- en vertaalbeleid makkelijk ongelijkheid en uitsluiting van nieuwkomers in de hand. Het draagt daardoor de kiem van haar contestatie in zich. Enerzijds is, zoals reeds aangehaald, radicale eentaligheid voor de betrokken overheden op lange termijn onverzoenbaar met hun nood aan democratische legitimering, anderzijds is ze een doorn in het oog van linguïstische minderheden. Vroeg of laat zullen overheden daarom zelf initiatieven nemen in de richting van institutionele meertaligheid en/of zullen bepaalde minderheidsgroepen voor 'hun' taal bepaalde rechten op taalgebruik en vertaling opeisen. Maar omdat discussies rond taal- en vertaalbeleid in (nationale, regionale, lokale) instellingen zo nauw verbonden zijn met fundamentele rechten en met machtsrelaties tussen de verschillende talen en hun sprekers, is de implementering van taal- en vertaalrechten voor minderheden niet alleen een continu maar veelal ook een moeizaam proces. Daarenboven is de link met integratie en identiteit vooralsnog onduidelijk. We komen hier nog op terug.

Het in vraag stellen van institutioneel monolinguïsme impliceert een evolutie van de afwezigheid van of het verbod op vertaling naar een affirmatief recht op vertaling in de minderheidstaal of -talen. De kritische drempel is vaak van kwantitatieve aard: de aanwezigheid van linguïstische minderheden in bepaalde steden of regio's is zo sterk dat het vertaalbeleid hieraan aangepast wordt. In een stad als Miami (Florida) spreekt $75 \%$ van de bevolking geen Engels thuis, terwijl 20\% van de inwoners van Californië slechts gebrekkig Engels spreekt. Steekproeven in Brussel wijzen in dezelfde richting: $20 \%$ van de Brusselaars spreekt thuis een andere taal dan Nederlands of Frans. In zulke situaties kunnen specifieke wettelijke bepalingen, naast 
allerhande niet-officiële ad hoc initiatieven, de beperkte aanwezigheid van de minderheidstaal of -talen in de publieke sfeer of in bepaalde instituties regelen. Deze wetten geven bijvoorbeeld het recht om openbare opschriften zoals wegwijzers, straatnamen en gebruiksaanwijzingen voor betaalautomaten in de minderheidstaal (of -talen) te vertalen. Ze voorzien het affirmatief recht op een vertaling van een officieel document of een tolk in bepaalde welomschreven omstandigheden: tijdens een gerechtszaak, voor medische verzorging, bij de overheidsadministratie enzovoort.

Wat België betreft zien we dat sommige Nederlandstaligen, twintig jaar na de Belgische onafhankelijkheid, de eentaligheid van de Belgische instituties in vraag begonnen te stellen. Hun eerste successen betreffen legale garanties voor vertaling van het Frans in het Nederlands in bepaalde domeinen van het publieke leven. Maar gedurende ongeveer één eeuw, tot ongeveer 1930, tasten ze de suprematie van het Frans niet aan. Vanaf 1870 versterken opeenvolgende taal- en vertaalwetten (zonder dat ze zo genoemd worden) de positie van het Nederlands naast die van het Frans in Vlaanderen voor wettelijke, juridische en administratieve zaken (Luykx 1985, Wils 1991). Dit vertaalbeleid is vergelijkbaar met de rechten die vandaag de dag aan migranten toegekend worden. De administratie van de Belgische staat, de provincies en de steden was bijvoorbeeld eentalig Frans, maar de richtlijnen voor het publiek mochten in het Nederlands vertaald worden, tenzij men dacht dat ze enkel het gecultiveerde publiek betroffen (Wils 1991: 58). De restricties die met dit recht op vertaling gepaard gaan, en de gebrekkige (financiële) middelen die veelal ter beschikking gesteld worden voor de uitvoering ervan, zorgen ervoor dat dit vertaalbeleid de dominante positie van de meerderheidstaal en haar sprekers niet in vraag stelt. Alleen afdwingbaar in bepaalde welomschreven omstandigheden (wat, waar, wanneer) tornt het niet aan de monolinguale ideologie. Vertaling blijft tijdelijk en occasioneel, met andere woorden, een uitzondering op de regel, in afwachting van de linguïstische assimilatie van de minderheden. Volgens tegenstanders van dit restrictieve vertaalbeleid bemoeilijkt het de integratie van migranten en werkt het hun gettovorming in de hand (zie bijvoorbeeld Schäffner 2008, Van Parijs 2007). Ook halen ze steevast uit naar de hoge kosten: zo zou het totale jaarbedrag voor meertalige immigratie- en naturalisatiediensten in de Verenigde Staten jaarlijks oplopen tot ongeveer 150 miljoen dollar (www.us-english.org/view). Vanaf het ogenblik dat niet-vertaling geen optie meer is, beperken overheden het recht op vertaling tot een oppervlakkige meertaligheid van bepaalde openbare diensten en instituties. Andere belangrijke instituties zoals het parlement of het leger blijven daarentegen eentalig: de beperkt afdwingbare rechten op vertaling in administratie, gerecht of openbare diensten 
tasten hun fundamentele eentaligheid nauwelijks aan. Hetzelfde geldt voor nationale symbolen zoals het volkslied, de nationale munt, postzegels enzovoort: zij blijven eentalig. Een mooi voorbeeld hiervan zijn de verhitte discussies rond de Spaanse vertaling van het Amerikaanse volkslied in april 2006. Volgens de tegenstanders illustreerde ze een weigering van de Spaanstaligen tot assimilatie en gaf ze verkeerdelijk het signaal als zouden de Verenigde Staten een tweetalig land zijn. De toenmalige president Bush schaarde zich achter de standpunten van de tegenstanders (zie ook: www.washingtontimes.com/news/2006/may/05/20060505-122343-2183r/). Ondanks de op het eerste gezicht uitgebreide vertaaldiensten die aan linguïstische minderheden geboden worden, is er dus een groot verschil tussen het statuut van het Engels in de Verenigde Staten enerzijds en dat van het Spaans, Chinees, Arabisch enzovoort anderzijds. Deze situatie is vergelijkbaar met het vertaalbeleid van Europese nationale overheden tegenover zogenaamde migrantentalen (Arabisch, Turks, Russisch). Institutioneel monolinguïsme gecombineerd met occasionele vertaling in de minderheidstaal (of -talen) wordt toegepast in vele hedendaagse maatschappijen. Het steunt op de idee dat de kennis van de geïnstitutionaliseerde (nationale) taal integratiebevorderend is en dat de kansen op maatschappelijk succes daarmee verhogen (Janssens 2001:167). Volgens sommige studies zijn de latino's in de Verenigde Staten ervan overtuigd dat Engels leren/ spreken essentieel is voor hun integratie (www.us-english.org).

\section{INSTITUTIONELE MEERTALIGHEID?}

Alternatieve types van taal- en vertaalbeleid kunnen een verdere verwijdering van monolinguïsme en occasionele vertaling in de richting van institutioneel multilinguïsme impliceren. Het meest extreme beleid opteert voor volledige institutionele meertaligheid, gebaseerd op multidirectionele verplichte vertaling op alle institutionele niveaus: altijd en overal vertaling van en naar alle mogelijke talen. Zo'n taal- en vertaalbeleid garandeert de absolute institutionele gelijkheid van alle betrokken talen en sprekers: alle burgers worden altijd en overal bediend in hun moedertaal. Tegelijkertijd maakt zo'n beleid de volledige eentaligheid van de individuele sprekers mogelijk. Meertaligheid van de instellingen laat met andere woorden eentaligheid van de burgers toe en is op die manier exact het tegenovergestelde van het reeds beschreven systeem van institutionele eentaligheid voor meertalige burgers. Het vertaalbeleid van de EU in haar relaties met de deelstaten vormt hier een goed voorbeeld van maar is, zoals reeds vermeld, 
beperkt tot de nationale talen. Alhoewel bijvoorbeeld Catalaans, Galicisch en Baskisch co-officiële regionale talen zijn in de respectievelijke Spaanse regios Catalonië, Galicië en Baskenland, behoren ze niet tot de officiële EUtalen zodat Europese richtlijnen enkel vertaald worden in het Spaans. Toch poogt de Europese Unie ook deze zogenaamde co-officiële regionale talen te erkennen. Om de communicatie van de burgers met de instellingen van de EU te vergemakkelijken, hebben de Europese ombudsman P. Nikiforos Diamandouros en de Spaanse regering in november 2006 een overeenkomst getekend om burgers toe te laten klacht in te dienen bij de Europese ombudsman in alle co-officiële talen van Spanje (Catalaans, Valenciaans, Galicisch, Baskisch). Volgens de overeenkomst zal de Spaanse regering een vertaaldienst oprichten die verantwoordelijk is voor de vertaling van de klachten uit het Catalaans, Valenciaans, Galicisch of Baskisch in het Spaans. Deze Spaanse vertaling zal doorgestuurd worden naar de ombudsman. De Spaanse antwoorden van de ombudsman zullen op hun beurt door dezelfde dienst vertaald worden uit het Spaans in de taal van de indiener van de klacht (zie www.ombudsman.europa.eu/release/en/2006-11-30a.htm).

Maar ook Frankrijk, een land dat bekendstaat om zijn cultus van de nationale taal, kende in het verleden een, weliswaar zeer korte fase van institutionele meertaligheid. Van januari 1790 tot juli 1793 hebben de Franse revolutionairen zowel de Verklaring van de Rechten van de Mens en van de Burger als de belangrijkste wetten vertaald in alle regionale talen. Volgens artikel 11 van de Verklaring met betrekking tot de vrijheid van meningsuiting, moest iedere Franse burger de wetten van de Republiek in zijn/haar eigen taal kunnen begrijpen. Mede door problemen zoals onervarenheid, hoge kosten en hoge werklast is er snel een einde gekomen aan dit meertalig beleid.

Indien hedendaagse nationale overheden dit type taal- en vertaalbeleid zouden willen invoeren voor al hun linguïstische minderheden, zou dit al snel tot een impasse leiden. Uiteraard zou de financiële last nog beduidend hoger liggen dan bij beperkte vertaling. In theorie zou daarenboven iedere nieuwe immigrant over volledige en in de tijd onbeperkte taal- en vertaaldiensten in zijn/haar taal moeten kunnen beschikken, met alle mogelijke risico's op gettovorming en isolatie vandien. In de praktijk lijkt volledige institutionele meertaligheid dan ook utopisch. Wel bestaan er allerhande tussenvormen: combinaties van institutioneel monolinguïsme en multilinguïsme als het ware. Ze zijn verbonden met de aanwezigheid van minderheidsgroepen (kwantitatieve voorwaarde) die op de een of andere manier historische territoriale rechten kunnen laten gelden. Voorbeelden hiervan 
(onderlinge verschillen niet in acht genomen) vinden we terug in officieel meertalige landen zoals België, Spanje, Canada, Zwitserland, Zuid-Afrika.

Het Belgische taal- en vertaalbeleid is een goede illustratie van de evolutie van institutionele eentaligheid naar institutionele meertaligheid. Deze evolutie is het resultaat van de taaleisen van de Nederlandstaligen, die hierin hun historisch territoriale rechten hebben kunnen laten gelden. In wat volgt geven we enkele belangrijke etappes. Ze volgden op het eerder vermelde systeem van restrictieve vertaling. Respectievelijk in 1886, 1888 en 1891 kregen munten, bankbriefjes en postzegels ook Nederlandstalige opschriften en werden ze dus tweetalig. Deze vertaling van Belgische nationale symbolen is nooit voorzien voor andere groepen: noch voor de Duitstalige minderheid die in 1920 in navolging van het Verdrag van Versailles geannexeerd werd noch voor de Italiaanse, Turkse en Marokkaanse migranten. In 1898 werd de zogenaamde Gelijkheidswet van kracht: vanaf dan moesten wetten niet alleen in het Frans maar ook in het Nederlands in het Belgisch Staatsblad verschijnen, zonder voorrang van de ene taal op de andere. In de praktijk werden de wetten eerst gedebatteerd en gestemd in het Frans en daarna vertaald in het Nederlands. De Belgische grondwet daarentegen bleef eentalig Frans tot in 1923, toen een speciale commissie belast werd met de Nederlandse vertaling. Deze verscheen in 1925 in het Staatsblad. In 1932 werd het Beknopt Verslag opgericht: deze dienst publiceerde een Nederlandse vertaling van de parlementaire debatten. Op dat ogenblik bestond het Franstalig Beknopt Verslag (Compte Rendu) al 60 jaar. Nog in 1932 werd de regeerverklaring voor de eerste keer in het Nederlands vertaald en voorgelezen. In 1936 introduceerde het Parlement simultaanvertaling van het Nederlands naar het Frans, omdat op dat ogenblik ongeveer één derde van de verkozen Vlamingen Nederlands sprak in het Parlement. Deze keuze voor het Nederlands had niets te maken met feitelijke taalkennis: alle verkozenen spraken voldoende Frans. Ze was een politiek statement om de eisen voor de verdere institutionele gelijkwaardigheid van het Nederlands kracht bij te zetten.

Precies op het ogenblik dat dit vertaalbeleid leidde tot een progressieve tweetaligheid van de Belgische politieke instellingen, legden de zogenaamde taalwetten de basis voor de institutionele eentaligheid van de administratie, het gerecht en het leger in Vlaanderen en Wallonië. In 1932 bepaalde een taalwet de eentaligheid van de gemeentelijke, provinciale en centrale administratie volgens het territorialiteitsprincipe: Nederlands in het noorden en Frans in het zuiden. Van dan af was administratieve vertaling in de 'andere' landstaal verboden, behalve voor enkele gemeenten rond Brussel en langs de taalgrens. Klachten als die van Van de Vyvere 
(1919) behoorden in het principe tot het verleden. Toch waren enkele uitzonderingsmaatregelen het voorwerp van kritiek. Voor communicatie met het publiek mochten de richtlijnen nog steeds in de 'andere' taal vertaald worden. In de praktijk betekende dit dat enkel in Vlaanderen mededelingen soms nog in het Frans vertaald werden. Sommige Nederlandstaligen beschouwden deze maatregel als een overtreding van het territorialiteitsprincipe, als een verdoken middel om de administratie in Vlaanderen tweetalig te houden en de Franstaligen in Vlaanderen te beschermen. Tegen het eind van de jaren dertig werd deze vertaalmodaliteit dan ook afgeschaft (von Busekist 1998: 246; Wils 1991: 66).

Een parallelle evolutie voltrok zich gedurende dezelfde periode in het leger en het gerecht. Twee wetten, respectievelijk in 1928 en 1938 regelden de verdeling van het leger in eentalige regionale divisies (Nederlands in het noorden en Frans in het zuiden). In 1935 bepaalde een wet dat de gerechtelijke procedure verplicht Nederlands was in Vlaanderen, Franstalig in Wallonië en in de taal van de verdachte of de verdediger in de tweetalige gemeenten (Wils 1991: 67). Eens te meer verbood deze evolutie het affirmatief recht op vertaling in de 'andere' nationale taal ten voordele van de institutionele emancipatie van de vroegere minderheidstaal. Dit taal- en vertaalbeleid streeft met andere woorden volledige gelijkheid van de betrokken talen en sprekers na, maar ieder in hun respectievelijk territorium. Intra-Belgische migratie impliceert geen affirmatief recht op vertaling.

$\mathrm{Na}$ de Tweede Wereldoorlog veranderde België progressief (1970, 1980, 1993) in een federale staat met twee eentalige regio's (Vlaanderen en Wallonië) en één tweetalige regio (Brussel) en met drie gemeenschappen, de Vlaamse, de Franstalige en de Duitstalige. De federale politieke instellingen (Kamer en Senaat) zijn bij wet tweetalig zodat alle wetten en documenten verplicht vertaald moeten worden in de andere taal (voor de Duitstalige gemeenschap gelden andere regels). Op het niveau van de gewesten en gemeenschappen is het verboden te vertalen, behalve in de zogenaamde faciliteitengemeenten. Het betreft o.a. 12 Nederlandstalige gemeenten langs de taalgrens met Wallonië en rond Brussel met faciliteiten voor Franstaligen en 4 Franstalige gemeenten langs de taalgrens met Vlaanderen met faciliteiten voor Nederlandstaligen. In deze gemeenten moeten de gemeentelijke diensten een vertaling van de administratieve documenten aanbieden, respectievelijk in het Frans en in het Nederlands. Sommige Vlamingen vinden dit automatisch recht op vertaling in contradictie met de op het territorialiteitsbeginsel gebaseerde institutionele eentaligheid. Daarom stipuleerde de omzendbrief Peeters in 1997, met betrekking tot het taalgebruik in de Vlaamse faciliteitengemeenten rond Brussel, dat iedere Frans- 
talige die een Franse vertaling van een Nederlandstalig document wenste, verplicht was deze vertaling expliciet keer op keer opnieuw te vragen.

De evolutie van het Belgische taal- en vertaalbeleid illustreert de institutionalisering van een voormalige minderheidstaal tot een meerderheidstaal in een bepaalde regio. Vanaf het ogenblik dat een minderheidstaal een meerderheidstaal wordt, gedraagt ze zich als dusdanig: institutionele vertaling wordt verboden of zo veel mogelijk beperkt tot occasionele situaties. Hetzelfde geldt voor het vertaalbeleid voor migranten. In sommige, welbepaalde situaties (gerecht, gezondheidszorg) hebben migranten in Vlaanderen of Wallonië recht op een vertaling in hun minderheidstaal. Dit verbod op vertaling op het regionale niveau gaat gepaard met een massieve vertaalpraktijk van verplichte vertaling van en naar de beide nationale talen op het tweetalige federale niveau. De evolutie is dus enorm. In één eeuw is de Belgische samenleving geëvolueerd van institutionele eentaligheid met verbod op vertaling, via beperkte tweetaligheid die bepaalde taalrechten voorzag voor de territoriale minderheden door middel van occasionele vertaling in welbepaalde situaties, naar een gemengd systeem van regionale eentaligheid met verbod op vertaling en federale tweetaligheid met verplichte vertaling. Territorium speelde hierin een sleutelrol. Het creëerde monolinguale eilanden onder een multilinguale paraplu en verhinderde mede dat multilinguïsme toegepast werd op alle institutionele niveaus.

\section{CONCLUSIE}

Zelfs in onze meertalige wereld van de eenentwintigste eeuw blijft de natiestaat en haar eentalige ideologie sterk. Participerend burgerschap voor linguïstische minderheden wordt zelden of nooit geïmplementeerd via volledige institutionele meertaligheid. De vraag is zelfs of dat wel wenselijk is. Zoals aangehaald is het antwoord op deze vraag alsnog onduidelijk. Ze vergt eerst en vooral grootschaliger onderzoek naar de relatie tussen vertaalbeleid, participerend burgerschap, integratie, identiteit en multiculturalisme. Want hoe dan ook is ieder debat over gelijke sociale, economische en politieke kansen in onze moderne meertalige samenlevingen per definitie een debat over taal- en vertaalbeleid. Dit is geen onschuldige conclusie. Het betekent dat een van de grootste uitdagingen voor de eenentwintigste eeuw het ontwerpen van een rechtvaardig taal- en vertaalbeleid is, niet alleen voor territoriale, maar ook voor migrantenminderheden. Dit vereist onder andere inzicht in de manier waarop vroegere en huidige samenlevin- 
gen hun vertaalbeleid geïmplementeerd hebben en wat de consequenties hiervan zijn. Hier ligt een grote uitdaging voor de vertaalwetenschap die zich tot nog toe niet of nauwelijks gebogen heeft over de politieke, ethische of etnische vraagstukken waarmee overheden voor het uittekenen van hun vertaalbeleid in de eenentwintigste eeuw zullen worstelen. Gelet op de vele taal- en vertaalstrubbelingen dreigt het inderdaad spannend te worden.

\section{BIBLIOGRAFIE}

Anderson, B., Imagined Communities, London-New York: Verso, $1991^{2}$.

Beukes, A-M., 'Governmentality and the good offices of translation in $20^{\text {th }}$-century South Africa', Southern African Linguistics and Applied Language Studies, 2007, 25-2, 115-130.

Beukes, A-M., 'Translation in SouthAfrica : the politics of transmission', Southern African Linguistics and Applied Language Studies, 2006, 24-1, 1-6.

Blackledge, A., Discourse and Power in a Multilingual World, Amsterdam: John Benjamins, 2005.

Blommaert, J. (ed), Language Ideological Debates, Berlin, Mouton de Gruyter, 1999.

Branchadell, A., 'Mandatory translation', in: Albert Branchadell, Lovell Margaret West, Less Translated Languages Less translated languages, Amsterdam \& Philadelphia: John Benjamins, 2004, 125-136.

Cronin, M., 'Altered states: translation and minority languages', TTR, 1995, 8:1, 85-104.

Delepeleire, Y., 'Pastoor weigert tweetalige mis', De Standaard, 14/o2/2008, http:// www.standaard.be/artikel/detail.aspx?artikelid=IB $21 \mathrm{~N}_{37}$ B\&word=pastoor+sintgenesius-rode

Freeland, J. en Patrick, D. (eds), Language Rights and Language Survival, Manchester: St. Jerome, 2004.

García de Toro, A. C., 'Translation between Spanish and Catalan today', in: Albert Branchadell, Lovell Margaret West, Less Translated Languages, , Amsterdam \& Philadelphia: John Benjamins, 2004, 269-288.

García González, M., 'Translation of minority languages in bilingual and multilingual communities', in: Albert Branchadell, Lovell Margaret West, Less Translated Languages Less translated languages, Amsterdam \& Philadelphia: John Benjamins, 2004, $105-123$.

Heller, M., 'Language choice, social institutions and symbolic domination', Language in Society, 1995, 24, 373-405.

Heller, M., Linguistic Minorities and Modernity. A Sociolinguistic Ethnography, London/New York, Longman, 1999.

Huyse, L., 'Breuklijnen in de Belgische samenleving', In: Huyse, L. \& Berting, J. (red.), Als in een spiegel? Een sociologische kaart van Belgie en Nederland, Leuven: Kritak, 1983, 9-25.

Hymes, D., Ethnography, Linguistics, Narrative Inequality: Toward an Understanding of Voice, London: Taylor and Francis, 1996.

Janssens, R., Taalgebruik in Brussel. Taalverhoudingen, taalverschuivingen en taalidentiteit in een meertalige stad, Brussel: VUBPress, 2001. 
K.L.D., 'Alleen Nederlands op markt Merchtem', De Standaard, 25/10/2005 http:// www.standaard.be/artikel/detail.aspx?artikelid=DMF25102005_029\&word=merc htem+markt.

Kaplan, R.B. en Baldauf R.B., Language Planning from Practice to Theory, Clevedon: Multilingual Matters, 1997.

Leman J. en Top J., Intercultureel en meertalig onderwijs, burgerschaps- en vredesopvoeding, Leuven: Garant, $2006^{2}$.

Luykx, T. en Platel, M., Politieke Geschiedenis van België (2 vol.), Antwerpen: Kluwer, 1985.

Meylaerts, R. "Et pour les Flamands la même chose”: quelle politique de traduction pour quelles minorités linguistiques?', Meta: journal des traducteurs, 2009, 54:1, 7-21.

Patten, A. en Kymlicka, W., 'Introduction. Language Rights and Political Theory : Context, Issues and Approaches', In: Patten, A. en Kymlicka, W. (eds.), Language Rights and Political Theory, Oxford: Oxford University Press, 2003, 1-51.

Schäffner, C., 'Behindert Übersetzung die Integration?', In: Vorderobermeier, G. en Wolf, M. (eds), 'Meine Sprache grenzt mich ab.... Transkulturalität und kulturelle Übersetzung im Kontext von Migration, Wien and Berlin: LIT Verlag, 2008, 169-188.

Schildkraut, D. J., Press One for English. Language Policy, Public Opinion, and American Identity, Princeton: Princeton University Press, 2005.

Stroud, C. en Heugh, K., 'Language Rights and Linguistic Citizenship', in: Freeland, J. en Patrick, D. (eds), Language Rights and Language Survival, Manchester: St. Jerome, 2004, 191-218.

Van de Vyvere, A., L'interpellation flamande, Bruxelles: Standaard, 1919.

Van Parijs, P. 'Linguistic diversity as curse and as by-product', In: Arzoz, X. (ed.), Respecting Linguistic Diversity in the European Union, Amsterdam, John Benjamins, 2007, 17-46.

Vermeulen, H. en Slijper, B., Multiculturalisme in Canada, Australië en de Verenigde Staten. Ideologie en Beleid, 1950-200o, Amsterdam: Aksant, 2003.

Von Busekist, A., La Belgique. Politique des langues et construction de l'Etat, Bruxelles, Duculot, 1998.

Wils, L. 'L'emploi des langues en matières judiciaires et administratives dans le royaume de Belgique', Revue du Nord. Histoire \& Archéologie. Nord de la France - Belgique - Pays-Bas, 1991, LXXIII, 51-71.

www.assemblee-nationale.fr/connaissance/constitution_1209.pdf

www.govtrack.us/congress/amendment.xpd? session $=110 \& a m d t=s 1151$

www.ombudsman.europa.eu/release/en/2006-11-30a.htm

www.us-english.org

www.washingtontimes.com/news/2006/may/05/20060505-122343-2183r/ 
